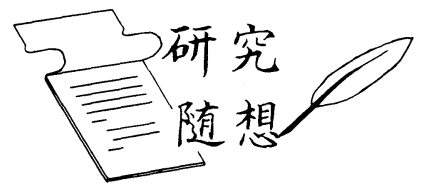

日本機械学会論文集 $(\mathrm{C}$ 編) 73 巻 735 号 $(2007-11)$

\title{
課題解決と図式表記法*
}

岸浪建史*1

\section{Graphical Language for Problem Solving}

\author{
Takeshi KISHINAMI*2 \\ ${ }^{* 2}$ Kushiro National College of Technology, \\ 2-23-1 Otanoshike, Kushiro-shi, Hokkaido, 084-0916 Japan
}

\begin{abstract}
Key Words: Metal Mold and Die, Numerical Control (NC), Milling, Computer Aided Manufacturing (CAM), Computer Aided Design (CAD), Rapid Prototyping, Product Development, Graphical Language
\end{abstract}

筆者は 1966 年に北海道大学工学部を卒業し大学院 に進学し, 修士研究として機械加工に関する研究課題 を模索していた。そのころ国産の大形計算機 (32ビッ トワードマシン, $64 \mathrm{k}$ ワードのメモリ)が開発され東 京大学に設置された時代でもあった. 1967 年の春, 精 機学会 (現在の精密工学会) 春季大会において, この大 形計算機を用いた東京大学生産技術研究所の吉村先生 の有限要素法プログラム開発とその応用事例に関する 特別講演は強烈な印象として今でも脳裹に残ってい る. 当時, 金属切削機構の塑性挙動の解析のために Visio-Plasticity 法を用いる研究を開始していた. Visio-Plasticity 法は金属素材の側面に格子状メッシ ュを刻印し, 変形中の格子メッシュ点の位置を読み取 り，その測定值からコンピュータを用いて塑性領域の ひずみ量, 変形量を求める手法で大量のデー夕処理が 必要であったことから大形計算機の利用はどうしても 避けられない状況にあったことがこの講演を聴く動機 となっていた.

この講演がきっかけとなって機械加工における静剛 性解析, 振動解析, 熱伝導解析のために有限要素法プ ログラム開発とその応用研究を行うこととなるが, 研 究を進めるに従って, 本来の機械加工に関する研究か ら離れつつあることを感じ始めていた。有限要素法は 変分原理に基づき単純な平面要素を用いて複雑な曲面

* 原稿受付 2007 年 6 月 13 日.

*1 正員, フェロ一, 釧路工業高等専門学校 (函 084-0916 釧路市 大楽毛西 2-23-1).

[著者略歷] 1944 年 1 月 2 日生まれ, 主として生産加工学, 特に曲 面加工法, 計算機制御曲面加工システム, 加工特徵認識とその工程 設計法, 機械加工におけるデータモデルの開発研究に従事, 2004 年 まで北海道大学工学研究科, 2007 年まで北海道大学理事, 現在は釧 路工業専門学校校長として勤務.

E-mail : kisinami@ office.kushiro-ct.ac.jp
の近似表現を求めていることから, 複雑な曲面の表現 方法に関する調查研究を進めていたこともあって, 研 究室の大きな研究課題であった NC工作機械を用い た曲面加工法の研究を分担することとなった. NC工 作機械による機械加工は単純幾何形状から構成される 機械部品加工に適用され, 金型等の曲面加工は倣い工 作機械を用いるのが主流で NC工作機械による曲面 加工は開発段階にあった。

筆者の研究室では倣い工作機械の機能と等価な機能 をミニコンピュータと NC工作機械の一体化によっ て実現できるのではないかと考え, 倣い工作機械で用 いる木型等の物理モデルを計算機内のディジタルモデ ルに置換え, そのディジタルモデルを基準にコンピュ 一夕の中で倣い操作を実行するソフトウェアに関する 研究を開始した. 研究課題は対象製品の曲面モデル生 成法, 工具切刃点が曲面モデルを破壊することなくモ デル表面との接触を保障する工具干渉回避方法の研 究, 倣い操作を可能とする工具駆動方式の研究, そし てこの概念を実現するため, 高精度ボールエンドミル の開発研究，ミニコンピュータと NC 装置とのハード 的接続と信号伝送方式の確保など多くの研究課題に恵 まれた.これらの研究課題は 5 年にわたって企業の協 力を受けながら優秀な多くの学生・技官の努力で研究 開発が成され, 当初の目標を達成することができた。 研究成果は学術論文として公表するだけでなく, 1982 年, 大阪で開催された第 5 回日本国際工作機械見本市 でデモンストレーションを行うと同時に, 開発したシ ステムは国内企業のみならず, 海外企業に対しても公 開された. 振り返ってみると, この研究課題は当時と しては数少ない産学連携研究でありながら典型的な目 的主導形の基礎研究であったといえる。 
機械工学に限らず，それぞれの学術分野・技術分野 で問題点を明らかにするためには, 種々の観点からの 対象の学術的・技術的検討が必要であることはいうま でもない. 一人の研究者が研究課題を見出す場合, 自 分自身の専門知識を総動員するだけでなく, 関連する 文献調査を行い，研究対象を取巻く観点として何があ るのかを調查し，その観点で対象をどのように認識し ているかを理解することが研究活動の初期段階で必要 となる。

研究開発をグループで行う場合, 同じ専門分野であ っても，個々の研究者の専門知識が異なるだけでなく 問題を認識する観点が異なるため, 研究対象の認識と 観点が広がり効率的研究遂行が可能となる. 特に企業 の研究者・技術者と大学の研究者の専門知識と観点は 大きく異なるため, 新たな発見につながる可能性が大 きいといえる，このことを組織的・定期的に実施する ために学会あるいは研究会が組織化され, 種々の観点 からの学術情報の交換の場が設定されている.さらに 個々の研究成果は学術論文として学会誌等に揭載さ れ，誰もが種々の観点から読める環境が用意されてい るともいえる.

しかし，研究分野が多岐に分かれるにつれ，対象の 認識と観点の専門化が進み, 対象の認識が他分野から ますます見えにくくなりつつある。人類が保持する知 識量は年々増加し, 12 年で倍になるとの指摘もある が, それを有効に活用し，新たな知識発見を加速する には, 知識構造を体系化し可視化する技術が必要とさ れている．特に視覚による情報伝達速度は文字列等に よる情報伝達速度の 2 けた上であるといわれているこ とから可視化技術は非常に重要であるといえる，図式 表記法(Graphical Language)は, 図式表記に必要な ルールを理解しておくことは重要であるが，視覚的情 報伝達手段であること，正確ではないが情報の全体と 部分を視覚的に瞬時に伝達できると同時に, 相互の関 連および関係を並列に表現できる特徵がある。研究室
における教員と学生の共同研究においても, 議論の全 体構造の共通認識あるいは議論の観点を共通に認識で きる点で図式表記法は極めて優れているといえる。

筆者の研究室では, 卒業研究・修士研究を実施する に当たって, 研究のプロセスの進め方と研究対象にお いて何が問題なのかを共通に認識するために, プロセ スに関しては IDEF 0 表記法 ${ }^{(1)}$, 対象の認識に関して は対象指向言語の一種である EXPRESS-G図式言 語(2)を長年用いてきた. もちろん, 研究窒へ初めて配 属される学生は, これらの図式表記法に慣れてはいな い. 研究課題となる対象の何が問題であるかを指導教 員と学生が共通に理解するため, 最初に EXPRESS$\mathrm{G}$ による対象の表現を試み，正確ではないが問題の全 体と部分の関係, 問題に関与する要因を分析し, 問題 の所在を大まかにつかむ作業から研究活動を開始して きた。もちろん指導教員も学生も EXPRESS-G 図式 言語を十分に知っているわけではないので，対象指向 モデリングの考え方に基づいた研究対象の EXPRESS-G 図式表記の努力を通して問題の本質を 理解する一助となったと思っている。一方, 問題解決 のためのプロセス (研究計画と研究手順)を相互に理解 するためにプロセス図式表示法の一種である IDEF 0 表記法を用いていた。これらの図式表記法の導入によ り研究対象の新たな観点, 研究計画・手順の不備を発 見することはまれではなかった，また，研究課題が異 なっても, 問題の構造および研究手順の認識の共有化 を促進し, 研究室の活性化と学生と教員のコミュニケ ーションに大きな効果を果たしたと信じている.

\section{文献}

(1) Federal Information Processing Standard 183: Integration Definition for Function Modeling.

(2) JIS B 3700-11, Industrial automation systems and integration-Product data representation and exchange-Part 11 Description methods: The EXPRESS language reference manual. 